\title{
On a mounted skeleton of apparently the extinct Cape Lion, Panthera leo melanochaita (Ch. H. Smith, 1842)
}

\author{
P.J.H. van Bree \\ Zoological Museum, University of Amsterdam, P.O. Box 94766, 1090 GT Amsterdam, the Netherlands
}

Keywords: Cape Lion, Panthera leo melanochaita, study of skeleton and painting, Museum Vrolik

\begin{abstract}
Recently, the skeleton of apparently a Cape Lion was discovered in the Zoological Museum of the University of Amsterdam. The history of the specimen as far as known is summarized and its attribution to Panthera leo melanochaita is elucidated with some measurements taken from the skeleton and the study of fur colours and manes" development on an oil painting of the same animal in the Rijksmuseum Amsterdam. Both the animal and the painting once belonged to King Louis Napoléon Bonaparte of Holland.
\end{abstract}

\section{History and skeleton study}

For quite some time there has been a mounted skeleton of a large lion (reg. nr ZMA 710) kept in the collections of the Zoological Museum in Amsterdam. Recently the skeleton came under scrutiny and the whole history of the object became known (Van Bree \& Welman, 1996).

When alive, the lion formed part of a travelling animal show under the management of Antoine Alpy that toured the Netherlands during the beginning of the 19th century. In July 1808 King Louis Napoléon, the Netherlands being at that time occupied by the French, ordered that the collection of animals of Alpy should be bought to form the nucleus of a menagerie he wanted to have, just like the one in Paris in the Jardin des Plantes (formerly named Jardin du Roi). The animals, among them two lionesses and the lion under discussion, were brought to Palace Soestdijk at Baarn and after a few months removed to an estate near the town of Haarlem. It was also intended to establish a Royal Botanical Garden there and for that purpose exotic plants were purchased (see Evers, 1941).
The menagerie of the king was enlarged by buying some other collections. Just as the animals were properly installed at Haarlem, the rather fickle King Louis Napoléon ordered on 22 May 1809 the removal of all the animals and plants to Amsterdam. There the animals were housed in the greenhouse of the town's botanical garden; the plants were put temporarily in the garden of a large house, the "Trippenhuis", which was the seat of what later would become the Royal Netherlands Academy of Sciences. In that same building was also housed the national art collection, which would become the state art museum, the Rijksmuseum, in Amsterdam.

During winter $1809 / 1810$ the animals went to empty barracks, so that the (sub)tropical plants could be placed in the greenhouse. On 10 June 1810, the king decided to dissolve the menagerie; on 2 July of the same year, under pressure of his brother emperor Napoléon Bonaparte, he abdicated and left the Netherlands. Finally on 30 September 1810 the remáinder of King Louis Napoléon's menagerie was sent to Paris. The lions were already dead by then.

During the time the menagerie was in Amsterdam, Gerardus Vrolik (1775-1859), professor of medicine and botany at the Athenaeum Illustre, was a member of the board of the Hortus Botanicus, the town's botanical garden and at the same time he was co-director of the menagerie. He started a museum very early in life, consisting of prepared human parts and zoological objects. The lion, which is the subject of this paper, died between May and August 1809 and professor Vrolik obtained the body of the animal for his museum. The museum "Mu- 


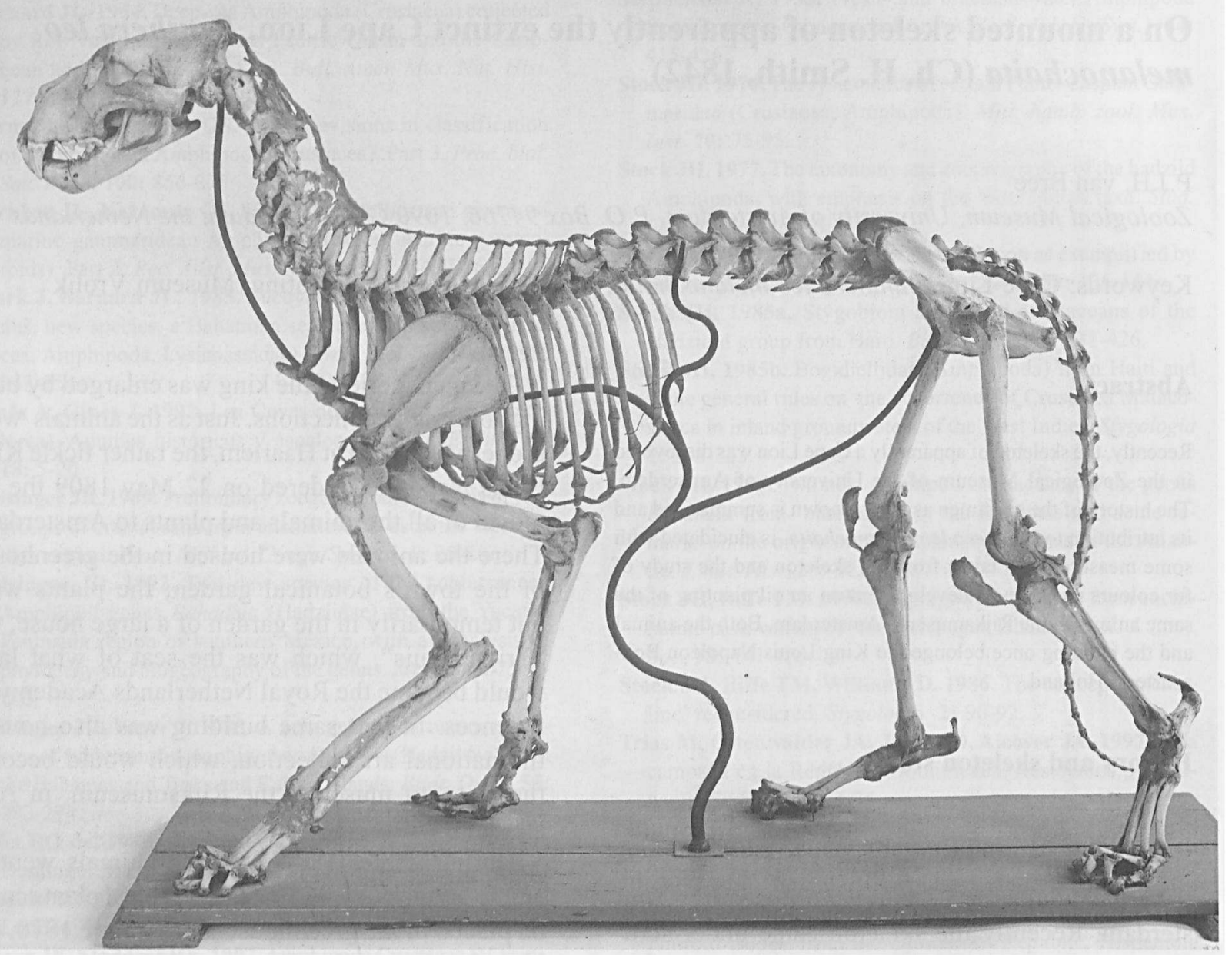

Fig. 1. Mounted skeleton of apparently the extinct Cape Lion, Panthera leo melanochaita (Ch. H.Smith, 1842) in the collection of the Zoological Museum Amsterdam. Photograph by L.A. van der Laan.

seum Vrolikianum" was enlarged considerably by his son, professor Willem Vrolik and became known as the best private museum in Europe at the time (Dusseau, 1865).

Willem Vrolik died in 1863 and it looked like the museum would have to be dissolved. However, funds were raised and in 1865 the collection was purchased from the heirs. All the medical objects were given to the town of Amsterdam for its Atheneum Illustre (the precursor of the University of Amsterdam) and the zoological part of the collection came into possession of the Zoological Society "Natura Artis Magistra", founded in 1838. This society administered a zoo, which still ex- ists, a zoological museum, an ethnographical museum and a library. When in 1892 the Amsterdam University started its own zoological museum, its staff also curated the society's collection until 1939. In that year the society's museum collections became officially part of the university's Zoological Museum (Smit, 1988).

In 1808, the Dutch painter P.G. van Os (1776 1839) submitted a painting of the male lion from the menagerie of the king to the exposition of modern art in the Netherlands. That exposition was an initiative of King Louis Napoléon. After the exposition the artist donated the painting to the king. It was incorporated in the state art collec- 


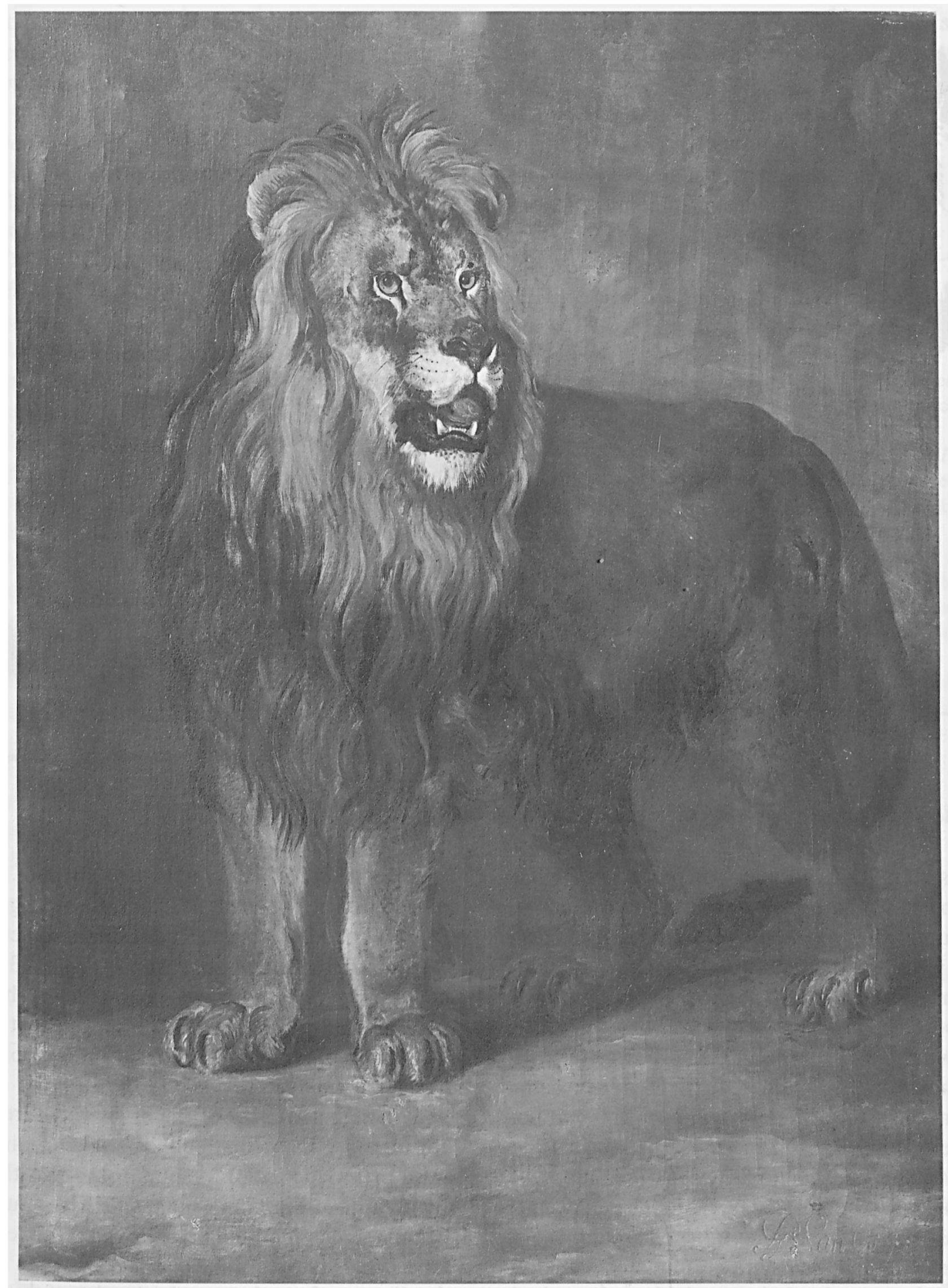

Fig. 2. Painting of the male lion in the menagerie of King Louis Napoléon by P.G. van Os. Collection Rijksmuseum Amsterdam.

tion, which after being housed at several places, is now in the Rijksmuseum (of art) in Amsterdam (see Fig. 2). Only recently we have become aware that the skeleton and the painting pertain to the same animal.

After examination of the painting of the lion, 


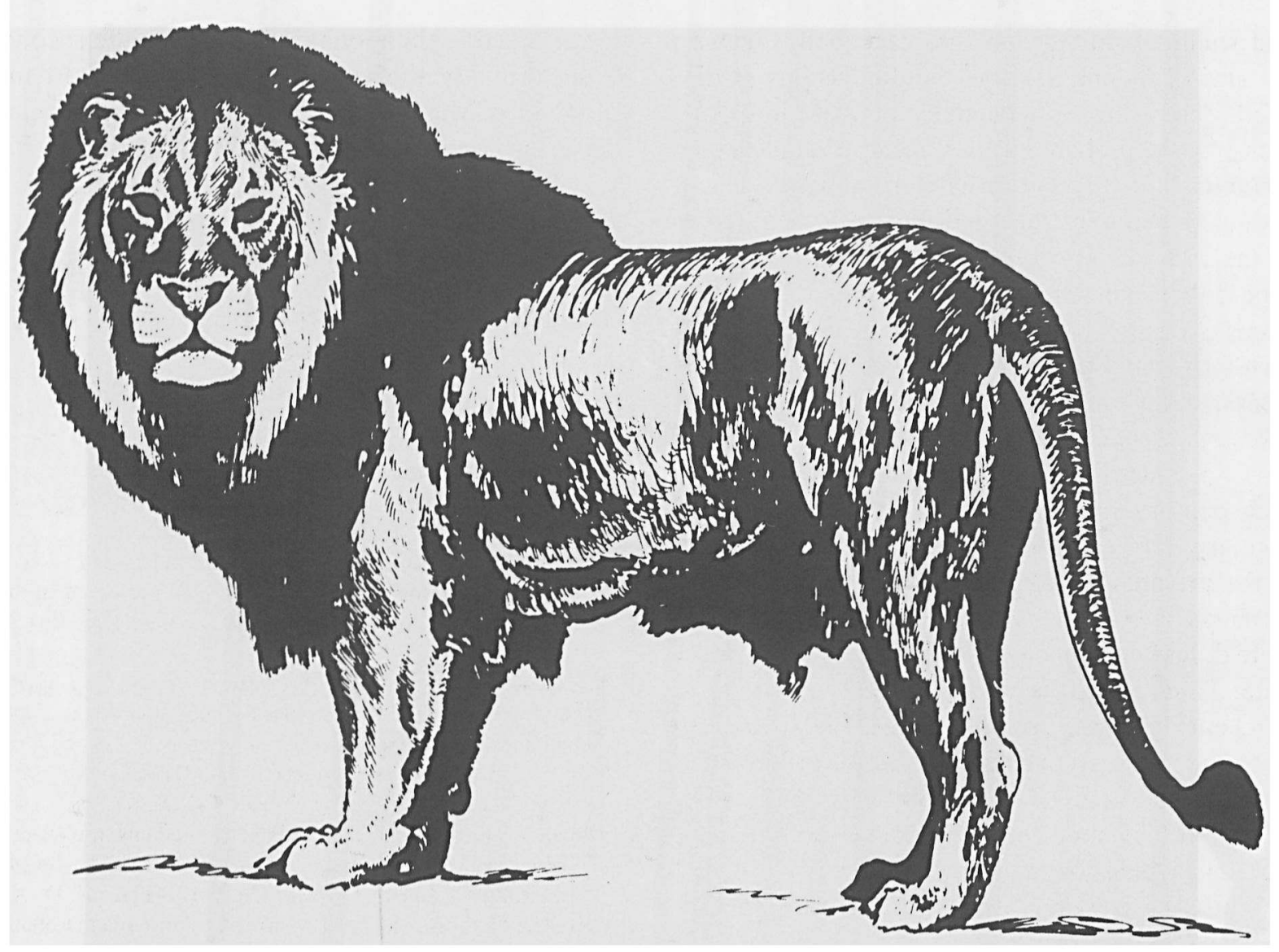

Fig. 3. How the Cape Lion probably looked in life. After Mazak, 1968.

with its long dark-coloured chest manes and its black belly manes, suspicion arose that the animal could be a Cape Lion. Therefore the skeleton and in particular the skull were studied in detail.

Thanks to the studies of the late Czechoslovakian zoologist Vratislav Mazák in the years 19601970, we know much about Cape Lions. He studied almost all the extant specimens in museums and furnished a good description of this extinct subspecies, which lived in the vast plains of the South African interior that lie west of the Great Eastern Escarpment (Mazák, 1975). The subspecies was most probably exterminated around 1850 .

The skull of the Amsterdam mounted skeleton is difficult to study. It is attached to the spinal column by a dried tendon (see Fig. 1) and skull and vertebrae are connected by dried tissue. Also the lower jaw is attached to the skull by dried tissue. Therefore accurate length measurements cannot be taken, but nevertheless some other meas- urements could be ascertained. To wit: rostral breadth $107 \mathrm{~mm}$, rostral depth $88 \mathrm{~mm}$, greatest length of nasals $96 \mathrm{~mm}$, prosthion-meatus acusticus externus $268 \mathrm{~mm}$, interorbital breadth $73 \mathrm{~mm}$, postorbital breadth $58 \mathrm{~mm}$, bizygomatic breadth $244 \mathrm{~mm}$, mastoid breadth $142 \mathrm{~mm}$, greatest height of mandible $112 \mathrm{~mm}$ (for the definitions of these measurements see Mazák, 1975: 40).

Although a number of important measurements are missing, those that could be taken point to a skull of a Cape Lion. In spite of the fact that the skeleton (see Fig. 1) is mounted in an unnatural way (it stands too high on its legs), it is clear that the animal was a large one. Measured with a tape, the distance from the anterior border of the nasals over the skull, over the tendon that connects the skull with the neural spines of the vertebrae till the last caudal vertebra, one arrives at a length of $256 \mathrm{~cm}$.

Taking into account the very dark coloured chest 
and shoulder manes and the black belly manes, the size of the animal, and the dimensions of the skull, one comes to the oonclusion that the specimen is most probably a Cape Lion, Panthera leo melanochaita. In addition circumstantial evidence should be taken into account. First, till the middle of the 19th century the only lions arriving in Europe either came from North Africa or from the Cape. Only after that time did lions also come from East Africa and India. In view of the painting it is clear that the lion under discussion is not a Barbary Lion, Panthera leo leo (Linnaeus, 1758). Secondly, the Cape was till 1795 a Dutch colony and in the 18th century living animals from South Africa regularly arrived in the Netherlands. For instance in the private Zoo of Stadtholder Prince William V many Cape animals could be seen. Some of them were described by the well-known zoologist Simon Peter Pallas when he visited the Hague between 1763 and 1767 (e.g., Wart Hog and Rock Dassie). As pointed out by Mazák \& Husson (1960), the famous Dutch artist Rembrandt (1606-1669), who never left his country, made a drawing of a reposing lion, which looks like a Cape Lion.

Thus taking everything into account, in spite of the fact that the early history of the lion before it came in the menagerie of King Louis Napoléon is unknown, it is highly probable that it was indeed a Cape Lion. The mounted skeleton is the second Cape Lion in the collection of the Amsterdam Zoological Museum. The first one, a mounted skin, has been described and pictured by Mazák in 1975 .

\section{References}

Bree PJH van, Welman W. 1996. Een leeuw van Lodewijk Napoleon. Amstelodamum 83 (6): 179-184.

Dusseau JL. 1865. Musée Vrolik: catalogue de la collection d'anatomie humaine, comparée et pathologique de M.M. Ger. et W. Vrolik. Amsterdam: De Roever Kröber.

Evers GA. 1941. Utrecht als koninklijke residentie - het verblïf van Lodewijk Napoleon te Utrecht 1807-1808. Utrecht: A.W. Bruna \& Zoon.

Mazák V. 1964. Preliminary list of the specimens of Panthera leo melanochaitus (Ch.H. Smith, 1842), preserved in the museums of the whole world in 1963. Z. Sâugetierk. 29 (1): $52-58$.

Mazák V. 1968. Der Lồwe. Das Pelzgewerbe 19 (3): 3-27.

Mazák V. 1975. Notes on the black-maned lion of the Cape, Panthera leo melanochaita (Ch. $\mathrm{H}$. Smith, 1842) and a revised list of the preserved specimens. Verhand. Kon. Ned. Akad. Wetensch. (Natuurk.) (2) 64: 1-44, XI pls.

Mazák V, Husson AM. 1960. Eínige Bemerkungen über den Kaplöwen, Panthera leo melanochaitus (Ch. H. Smith, 1842), Zoöl. Meded. (Leiden), 37 (7): 101-111, pls. IX-X.

Smit P. 1988. Artis - een Amsterdamse tuin. Amsterdam: Rodopi.

Received: 26 May 1998 